\title{
Real life profile of asthma and chronic obstructive pulmonary disease patients in Turkey
}

\author{
Zeynep MISIRLIGIL ${ }^{1}$ \\ Arif ÇIMRIN ${ }^{2}$ \\ Hakan GÜNEN ${ }^{3}$ \\ Tevfik ÖZLÜ ${ }^{4}$ \\ Aykut ÇiLLi ${ }^{5}$ \\ Levent AKYILDIZ ${ }^{6}$ \\ Hasan BAYRAM ${ }^{7}$ \\ Bilun GEMICIOĞLU ${ }^{8}$ \\ Esra UZASLAN ${ }^{9}$ \\ Öznur ABADOĞLU 10 \\ Mecit SUERDEM ${ }^{11}$
}

${ }^{1}$ Department of Chest Diseases, Faculty of Medicine, Ankara University, Ankara, Turkey

1 Ankara Üniversitesi Tıp Fakültesi, Göğüs Hastalıkları Anabilim Dalı, Ankara, Türkiye

2 Department of Chest Diseases, Faculty of Medicine, Dokuz Eylul University, Izmir, Turkey

${ }^{2}$ Dokuz Eylül Üniversitesi Tıp Fakültesi, Göğüs Hastalıkları Anabilim Dalı, Izmir, Türkiye

${ }^{3}$ Clinic of Chest Diseases, Istanbul Umraniye Training and Research Hospital, Istanbul, Turkey

3 istanbul Ümraniye Eğitim ve Araştırma Hastanesi, Göğüs Hastalıkları Kliniği, istanbul, Türkiye

${ }^{4}$ Department of Chest Diseases, Faculty of Medicine, Karadeniz Technical University, Trabzon, Turkey

${ }^{4}$ Karadeniz Teknik Üniversitesi Tıp Fakültesi, Göğüs Hastalıkları Anabilim Dalı, Trabzon, Türkiye

${ }^{5}$ Department of Chest Diseases, Faculty of Medicine, Akdeniz University, Antalya, Turkey

${ }^{5}$ Akdeniz Üniversitesi Tıp Fakültesi, Göğüs Hastalıkları Anabilim Dalı, Antalya, Türkiye

${ }^{6}$ Clinic of Chest Diseases, Private Mardin Park Hospital, Mardin, Turkey

${ }^{6}$ Özel Mardin Park Hastanesi, Gögüs Hastalıkları Kliniği, Mardin, Türkiye

7 Department of Chest Diseases, Faculty of Medicine, Gazi University, Ankara, Turkey

${ }^{7}$ Gazi Üniversitesi Tıp Fakültesi, Gögüs Hastalıkları Anabilim Dalı, Ankara, Türkiye

${ }^{8}$ Department of Chest Diseases, Faculty of Cerrahpasa Medicine, Istanbul University, İstanbul, Turkey

${ }^{8}$ İstanbul Üniversitesi Cerrahpaşa Tıp Fakültesi, Gögüs Hastalıkları Anabilim Dalı, Istanbul, Türkiye

${ }^{9}$ Department of Chest Diseases, Faculty of Medicine, Uludag University, Bursa, Turkey

${ }^{9}$ Uludağ Üniversitesi Tıp Fakültesi, Göğüs Hastalıkları Anabilim Dalı, Bursa, Türkiye

${ }^{10}$ Department of Chest Diseases, Faculty of Medicine, Cumhuriyet Unıversity, Sivas, Turkey

${ }^{10}$ Cumhuriyet Üniversitesi Tıp Fakültesi, Göğüs Hastalıkları Anabilim Dalı, Sivas, Türkiye

${ }^{11}$ Department of Chest Diseases, Faculty of Medicine, Selcuk University, Konya, Turkey

11 Selçuk Üniversitesi Tıp Fakültesi, Göğüs Hastalıkları Anabilim Dalı, Konya, Türkiye

\section{Yazışma Adresi (Address for Correspondence)}

Dr. Zeynep MISIRLIGIL

Ankara Üniversitesi Tıp Fakültesi, Göğüs Hastalıkları Anabilim Dalı, Beşevler, ANKARA - TURKEY

e-mail:drmisirli@gmail.com 


\section{SUMMARY}

\section{Real life profile of asthma and chronic obstructive pulmonary disease patients in Turkey}

Introduction: Despite the presentation of similar symptoms, the airway diseases have different underlying pathophysiological processes and must be distinguished to enable the administration of appropriate treatment. In several studies the clinician- and patient-related causes of poor compliance to treatment in asthma/chronic obstructive pulmonary disease (COPD) patients have been evaluated. This study aimed to determine the clinical and sociodemographic characteristics of newly diagnosed treatment-naïve asthma and COPD patients in Turkey.

Materials and Methods: This national, multicentre, prospective, observational study was conducted in 122 centres. A questionnaire including items related to demographic, clinical, laboratory parameters was applied. All patients were intended to be followed-up for 12 months.

Results: 1892 adult patients (1116 asthma and 776 COPD) from 122 centres were enrolled. Overall 95\%, 86\% and 65\% of intermittent, mild persistent and moderate persistent asthma patients were over-treated. Among COPD patients, the percentages of over-treated patients were $66 \%, 79 \%$ and $82 \%$ for those with GOLD stage A, B and C. Physicians' adherence to guidelines was appropriate in $93 \%$ of severe persistent asthma patients and $89 \%$ of GOLD stage D COPD patients. Among patients with high compliance to treatment, proportion of asthma patients with total control was $44 \%$ and that of COPD patients at GOLD stage $A$ was $41 \%$. In consecutive two visits, this figure increased to $52 \%$ and $63 \%$ in asthma patients and $54 \%$ and $50 \%$ in COPD patients.

Conclusion: The main findings are: (a) patients are frequently over-treated and (b) patients do not adhere to visits as expected, in both asthma and COPD.

Key words: Asthma, chronic obstructive pulmonary disease; COPD, Guideline adherence; real-life study; compliance

\section{ÖZET}

\section{Türkiye'de astım ve kronik obstrüktif akciğer hastalığı olan hastalarda gerçek yaşam profili}

Giriş: Benzer semptomlar göstermelerine rağmen hava yollarının hastalıkları altta yatan farklı patofizyolojik olaylara sahiptir ve uygun tedavinin uygulanabilmesi için ayırt edilmeleri gerekir. Astım/kronik akciğer hastalığı (KOAH) hastalarındaki tedaviye uyum zayıflı̆̆ının klinisyen ve hasta ile ilişkili nedenleri çok sayıda çalışmada değerlendirilmiştir. Bu çalışmada, Türkiye'deki yeni tanı almış tedavisiz astım ve KOAH hastalarının klinik ve sosyodemografik özelliklerini belirlemek amaçlanmıştır.

Materyal ve Metod: Bu ulusal, çok merkezli, gözlemsel çalışma 122 merkezde yürütülmüştür. Demografik, klinik, laboratuvar parametreleri ile ilişkili kriterleri içeren bir anket kullanılmıştır. Tüm hastaların 12 ay süreyle izlenmesi planlanmıştır.

Bulgular: Çalışmaya122 merkezden 1892 erişkin hasta (1116 astım ve 776 KOAH) alınmıştır. Intermitan, hafif persistan ve orta persistan astım hastalarının sırasıyla \%95, \%86 ve \%65'i aşırı tedavi görmektedir. KOAH hastaları arasında, aşırı tedavi görenlerin yüzdeleri GOLD evre A, B ve C için sırasıyla \%66, \%79 ve \%82'dir. Tedaviye uyumu yüksek hastalar arasında tam kontrol altındaki hasta oranı astım hastalarında \%44, GOLD evre A KOAH hastalarında \%41'dir. Art arda iki vizitte, bu oran astım hastalarında \%52 ve \%63'e, KOAH hastalarında \%54 ve \%50'ye artma göstermiştir.

Sonuç: Başlıca sonuçlar; astım ve KOAH'ı hastalar (a) sıklıkla aşırı tedavi almaktadır ve (b) tahmin edilebileceği gibi vizitlere uyum göstermemektedir.

Anahtar kelimeler: Astım, kronik obstrüktif akciğer hastalığı; KOAH, rehbere uyum; gerçek yaşam çalışması; kompliyans

\section{INTRODUCTION}

Asthma and chronic obstructive pulmonary disease (COPD) are the two most common respiratory conditions causing airflow limitation through an interaction involving different sensitizing agents, different cell populations in the airway inflammatory process, and different degrees of reversibility. Airway obstruction is typically fully or nearly fully reversible in patients with asthma, whereas COPD is characterized by airway obstruction that is not fully reversible $(1,2)$.

Despite the presentation of similar symptoms, such as dyspnoea, cough and wheezing, airway diseases have different underlying pathophysiological processes and must be distinguished to enable the administration of appropriate treatment. Implementing best practice management for airways disease is a critical goal for health-care systems -the management now includes pharmacological and non-pharmacological approaches to the lung disease, as well as recognition and treatment of comorbidities. Since systemic effects as well as local lung consequences have been reported in both asthma and COPD, multidimensional analyses are likely to be important for disease control $(3,4)$. Some patients 
having respiratory symptoms might be misdiagnosed due to atypical case presentation, insufficient etiological investigation or overlapping of diseases. Although asthma and COPD have distinct characteristics, both cause chronic inflammation of the airways and have certain risk factors which are common. Thus, comprehensive assessments should be conducted concerning any risk factors or exposure, time of onset and severity of the presenting exacerbation and of previous exacerbation episodes, medication use, comorbidities, prior hospitalizations, history of respiratory failure, and other information in the course of a differential diagnosis. Briefly, the assessment of asthma and COPD is required to determine the severity of the disease, its impact on health status and the risk of future events (e.g. exacerbations, hospital admissions or death) and is essential to guide therapy. When the clinical history of a patient who is suspected to have or is at high risk for obstructive airway disease is being taken, a proactive approach is warranted.

Compliance to treatment is still a major problem in all chronic diseases. Compliance to pharmacological treatment in asthma and COPD, in particular, is known to be low. Increase in exacerbations and hospitalization rate in asthma patients could be associated with poor compliance to treatment. In several studies the clinician- and patient-related causes of poor compliance to treatment in asthma/COPD patients have been evaluated $(5,6)$. Şen et al. also studies this issue in Turkish population (7). Thus, this study was designed to evaluate the physician-, patient- and environment-related aspects of compliance to treatment in newly diagnosed treatment-naïve asthma/ COPD patients to reveal the current status in Turkey. As it is the first nationwide study on this area in real life, we believe that our findings will have a beneficial impact on asthma/COPD patients' health and healthcare costs.

\section{MATERIALS and METHODS}

\section{Study Design}

This study is a national, multicentre, prospective and non-interventional study focused on the diagnosis and treatment approaches under real life conditions, aiming to observe the natural progression of asthma and COPD. The study protocol was approved by the Erciyes University Faculty of Medicine Ethics Committee (February 10, 2012). The study was conducted between June 2012 and March 2014.

Patients were enrolled based on GINA (Global Initiative for Asthma) 2012 for asthma and GOLD (Global
Initiative for COPD) 2011 for COPD $(8,9)$. A standard web-based questionnaire including items related to demographic, clinical, laboratory and treatment parameters was applied to patients. All procedures were administered by the investigators at 122 centres, and supervised by the Executive Board consisting of 11 asthma/COPD specialists with the help of an authorized contract research organization.

\section{Patients}

To select the study patients and to avoid bias, the physicians screened all patients consecutively and all eligible patients were informed about the study. Asthma/COPD patients meeting the inclusion criteria below were included in the study:

- Age of diagnose: $\geq 18$ - $\leq 80$ years for asthma and $\geq 40$ - $\leq 80$ years for COPD patients.

- Diagnosis of asthma/COPD in the previous three months at latest or after the initiation visit.

- Patients who have not taken asthma/COPD maintenance treatment except short-acting beta agonists.

- Diagnosis of asthma/COPD which was validated via respiratory function tests.

- Patients (or their legal representatives) who accepted to sign the informed consent form.

\section{Procedures and Measures}

A "Case Report Form" was prepared by the Executive Board and contract research organization. Data included the information written on patient's routine medical records. Previous and current medical history data collected at the initiation visit included: the referral information; demographics (the region of life spent longest, the region of life spent in last three months, height, body weight, body mass index and education status); aetiology; medical history (reasons of application, concomitant diseases, family history); risk factors (smoking, occupation, trigger factors, heating and cooking methods); diagnostic tests (including spirometry); disease severity (GINA severity table for asthma and GOLD criteria for COPD); asthma phenotype; and treatment.

After the initial visit, all patients were followed-up for 12 months. Intended timing for the visits were 0-1 month for visit-1, 1-3 months for visit-2 and 3-12 months for visit-3, however, the frequency of the visits was not determined by the study protocol; physicians were completely free to plan the follow-up procedures. Data on disease progression and outcome collected 
during the follow-up visits included the information on admission (reason for admission, hospitalization, signs and symptoms), assessment of disease control (asthma control test for asthma and GOLD assessment for COPD), assessment of compliance to treatment, and spirometric examination if needed by the physician. Compliance of the patients' to medication was evaluated by the physician at each visit using a scale. According to this scale, "high compliance" defines the patients who use medications regularly, "medium compliance" and "low compliance" terms define those who use medications with partial or severe interruptions, respectively. And finally, "noncompliance" defines the patients who did not use medication.

\section{Data Management}

Physicians were blind to patients of other centres. All lower/upper limits regarding the laboratory test results, decimals, birth dates, etc. were identified in the software and entries out of limits were not allowed. System retrieved and weekly updated the package information (name, dosage, pharmaceutical form) of all the medications from the list at the web site of Turkish Drug and Medical Device Institution (www. iegm.gov.tr) and allowed physicians to choose the correct and valid name of medication.

To improve data quality, the audit visits were performed at 20 centres ( $15 \%$ of all) which included 450 patients (22\% of all) and data were compared with the source documents. Data were protected at high capacity servers located at data centre of Türk Telekom (communication and substructure provider company). System equipments were designed binary so as to provide back-up in case of any breakdown. Security of the system was provided with software like firewall, antivirus, antispam, IPS (Intrusion Prevention System) and VPN (Virtual Private Network). SSL/VPN (Secure Socket Layer/Virtual Private Network) technology was used for encryption of data base. To ensure the secure data transfer, a "https://" (Hyper Text Transfer Protocol Secure) link was used.

\section{Statistical Analysis}

The primary objective of the study was to determine the physicians' approach towards asthma/COPD patients. Sample size calculation was based on to detect the frequency of least common approach (which was set at "used in at least $5 \%$ of the patients") within $\pm \% 1$ error and $95 \%$ confidence interval. With these assumptions, the number of patients to be enrolled was calculated as 1817 .
Patients' demographics and disease characteristics were presented with descriptive statistics. Group comparisons were performed using chi-square test and Student's $t$ test. For the comparison of numeric variables among more than two groups, one-way variance analysis (ANOVA) followed by Tukey HSD test was used. For the comparison of proportions in conditions with low number of cases, Fisher chisquare test and for the comparison of ordinal proportions, Mantel-Haenszel chi-square test was used.

Table 1. Demographic characteristics of patients with asthma/chronic obstructive pulmonary disease (COPD)

\begin{tabular}{|c|c|c|c|}
\hline & $\begin{array}{c}\text { Asthma } \\
\text { patients } \\
(n=1116)\end{array}$ & $\begin{array}{c}\text { COPD } \\
\text { patients } \\
(n=776)\end{array}$ & $p$ value \\
\hline Female (\%) & 64.4 & 11.9 & $<0.001^{*}$ \\
\hline $\begin{array}{l}\text { Age (years) } \\
(\text { mean } \pm S D)\end{array}$ & $42.5 \pm 13.7$ & $59.4 \pm 9.1$ & $<0.001^{* *}$ \\
\hline $\begin{array}{l}\text { Age groups } \\
\text { (years) (\%) }\end{array}$ & & & $<0.001^{* * *}$ \\
\hline$<40$ & 27.0 & - & \\
\hline $40-49$ & 23.1 & 15.5 & \\
\hline $50-59$ & 18.8 & 36.9 & \\
\hline $60-69$ & 9.1 & 32.3 & \\
\hline$\geq 70$ & 3.1 & 15.3 & \\
\hline BMI $\left(\mathrm{kg} / \mathrm{m}^{2}\right)(\%)$ & & & $<0.001^{* * *}$ \\
\hline$<25$ & 34.3 & 44.4 & \\
\hline $25-29.9$ & 32.6 & 32.2 & \\
\hline$\geq 30$ & 33.1 & 23.5 & \\
\hline Smoking status (\%) & & & $<0.001^{* * *}$ \\
\hline Smoker & 27.9 & 56.3 & \\
\hline Ex-smoking & 15.0 & 38.1 & \\
\hline Passive smoker & 12.6 & 2.2 & \\
\hline Nonsmoker & 44.4 & 3.4 & \\
\hline Education (\%) & & & $<0.001^{* * *}$ \\
\hline Illiterate & 12.6 & 11.1 & \\
\hline $\begin{array}{l}\text { Elementary } \\
\text { school }\end{array}$ & 42.8 & 55.5 & \\
\hline $\begin{array}{l}\text { Secondary } \\
\text { school }\end{array}$ & 12.1 & 11.7 & \\
\hline High school & 19.0 & 15.5 & \\
\hline University & 13.5 & 6.2 & \\
\hline Living area (\%) & & & $<0.001^{*}$ \\
\hline Urban & 67.3 & 59.3 & \\
\hline Rural & 19.4 & 27.0 & \\
\hline Mixed & 13.2 & 13.7 & \\
\hline Family history (\%) & 57.9 & 37.3 & $<0.001^{*}$ \\
\hline \multicolumn{4}{|c|}{$\begin{array}{l}\text { * Chi-square test, } \\
\text { ** Student's t test, } \\
* * * \text { Mantel-Haenszel chi-square test. }\end{array}$} \\
\hline
\end{tabular}


Table 2. Disease severity and comorbidities of patients with asthma/chronic obstructive pulmonary disease (COPD)

\begin{tabular}{|c|c|c|c|}
\hline \multicolumn{2}{|c|}{ Asthma patients $(n=1096)$} & \multicolumn{2}{|c|}{ COPD patients $(n=765)^{*}$} \\
\hline Disease severity & $\%$ & Disease severity & $\%$ \\
\hline Intermittent & 9.6 & GOLD stage $A$ & 25.7 \\
\hline Mild & 37.0 & GOLD stage $B$ & 39.2 \\
\hline Moderate & 45.0 & GOLD stage $C$ & 28.5 \\
\hline Severe & 8.5 & GOLD stage D & 6.6 \\
\hline Comorbidities & $\%$ & Comorbidities & $\%$ \\
\hline Any comorbidity & 53.9 & Any comorbidity & 52.8 \\
\hline URT disorder & 25.1 & Hypertension & 21.1 \\
\hline Hypertension & 13.9 & CAD & 13.6 \\
\hline Gastroesophageal reflux & 9.0 & DM & 10.1 \\
\hline DM & 6.5 & Gastric reflux & 4.6 \\
\hline
\end{tabular}

\section{RESULTS}

A total of 1892 newly diagnosed treatment-naïve adult patients (1116 with asthma and 776 with COPD) from 122 centres were included in the analysis.

Table 1 demonstrates the demographic characteristics of the patients included in the analysis. When compared with COPD, proportion of female patients was higher in asthma (chi-square test, $\mathrm{p}<0.001$ ). Asthma patients were younger, more overweighted, less smoker, more educated, more had lived in urban areas and more had family history than COPD patients (all $p$ values $<0.05$ ).

Upper respiratory tract disorders ( $25.1 \%$ vs. $2.8 \%)$ and family history including allergic disease $(6.5 \%$ vs. $1.5 \%$ ) are more frequent in asthma as compared to COPD (chi-square test, both $\mathrm{p}$ values $<0.001$ ). Occupational exposure to dusts and fumes is more frequent in asthma than in COPD $(37.0 \%$ vs. $25.2 \%$; chi-square test, $\mathrm{p}<0.001)$. Evaluation of the phenotypes revealed that more than half of the asthma patients $(51.2 \%)$ had non-allergic phenotype. In asthma, the major reasons for hospital admission are $91.0 \%$ dyspnoea, $83.7 \%$ cough, $79.1 \%$ wheezing, $71.0 \%$ tightness in the chest, and $47.3 \%$ sputum. In COPD patients, the major reasons for hospital admission are $94.4 \%$ dyspnoea, $84.6 \%$ cough, $73.2 \%$ sputum, $62.5 \%$ wheezing, and $56.9 \%$ tightness in the chest. In both groups, air pollution is the main trigger factor
$(65.4 \%$ and $60.7 \%$, for asthma and COPD, respectively).

$45.0 \%$ of the asthma patients had moderate and $37.0 \%$ had mild persistent asthma. Among COPD patients, $39.2 \%$ had stage $B$ and $28.5 \%$ had stage $C$ disease severity according to GOLD criteria (Table 2). $53.9 \%$ of asthma and $52.8 \%$ of COPD patients had comorbidities. The most frequently observed comorbidities are the upper respiratory system disorders, hypertension, and gastroesophageal reflux in asthma, and hypertension, coronary artery disease and diabetes mellitus in COPD (Table 2).

Table 3 and Figure 1 show the adherence of the physicians to clinical guidelines in terms of medications used by the patients with different disease severity stages. According to the analysis, the majority of the asthma patients with intermittent, mild persistent and moderate persistent disease severity are over-treated, i.e. treated more aggressively than recommended in the clinical practice guidelines $(95 \%, 86 \%$ and $65 \%$, respectively). Among COPD patients, the percentages of over-treated patients are $66 \%, 79 \%$ and $82 \%$ for those with GOLD stage A, B and C, respectively. The adherence level of the physicians to guidelines seems to be appropriate in $93 \%$ of the asthma patients with severe persistent disease severity and $89 \%$ of the COPD patients with GOLD stage D. 


\begin{tabular}{|c|c|c|c|c|c|}
\hline \multirow[t]{2}{*}{ Adherence to guidelines } & \multicolumn{5}{|c|}{ Asthma patients $(n=1085)$} \\
\hline & Total & $\begin{array}{c}\text { Intermittent } \\
(n=104)\end{array}$ & $\begin{array}{l}\text { Mild persistent } \\
\quad(\mathrm{n}=398)\end{array}$ & $\begin{array}{c}\text { Moderate } \\
\text { persistent } \\
(n=490)\end{array}$ & $\begin{array}{c}\text { Severe persistent } \\
(n=93)\end{array}$ \\
\hline Appropriate & 29.1 & 4.8 & 13.3 & 35.1 & 92.5 \\
\hline Over-treatment & 70.4 & 95.2 & 86.2 & 64.5 & 6.5 \\
\hline Under-treatment & 0.5 & 0.0 & 0.5 & 0.4 & 1.1 \\
\hline \multirow[t]{3}{*}{$p$ value } & & & $<0.001$ & & \\
\hline & \multicolumn{5}{|c|}{ COPD patients $(n=708)$} \\
\hline & Total & $\begin{array}{c}\text { GOLD stage } A \\
(n=183)\end{array}$ & $\begin{array}{c}\text { GOLD stage B } \\
(n=277)\end{array}$ & $\begin{array}{c}\text { GOLD stage } C \\
(n=201)\end{array}$ & $\begin{array}{c}\text { GOLD stage D } \\
(n=47)\end{array}$ \\
\hline Appropriate & 27.8 & 33.9 & 20.9 & 17.4 & 89.4 \\
\hline Over-treatment & 71.8 & 66.1 & 78.7 & 81.6 & 10.6 \\
\hline Under-treatment & 0.4 & 0.0 & 0.4 & 1.0 & 0.0 \\
\hline$p$ value & & & $<0.001$ & & \\
\hline
\end{tabular}

\section{Follow-up of the Patients}

Figure 2 demonstrates the disease control level of the asthma patients with different levels of compliance to treatment during the follow-up period. Among those with high treatment compliance at visit- $1,44 \%$ were totally controlled. Total control rate improved and reached to $52 \%$ at visit-2 and to $63 \%$ at visit-3. Among those with high treatment compliance, the percentage of patients with uncontrolled disease was only $5 \%$ in all three visits.

In a similar fashion, among COPD patients with high treatment compliance, $41 \%$ had GOLD stage A disease severity at visit- 1 . This level was $54 \%$ at visit- 2 and $50 \%$ at visit-3. During the follow-up, the

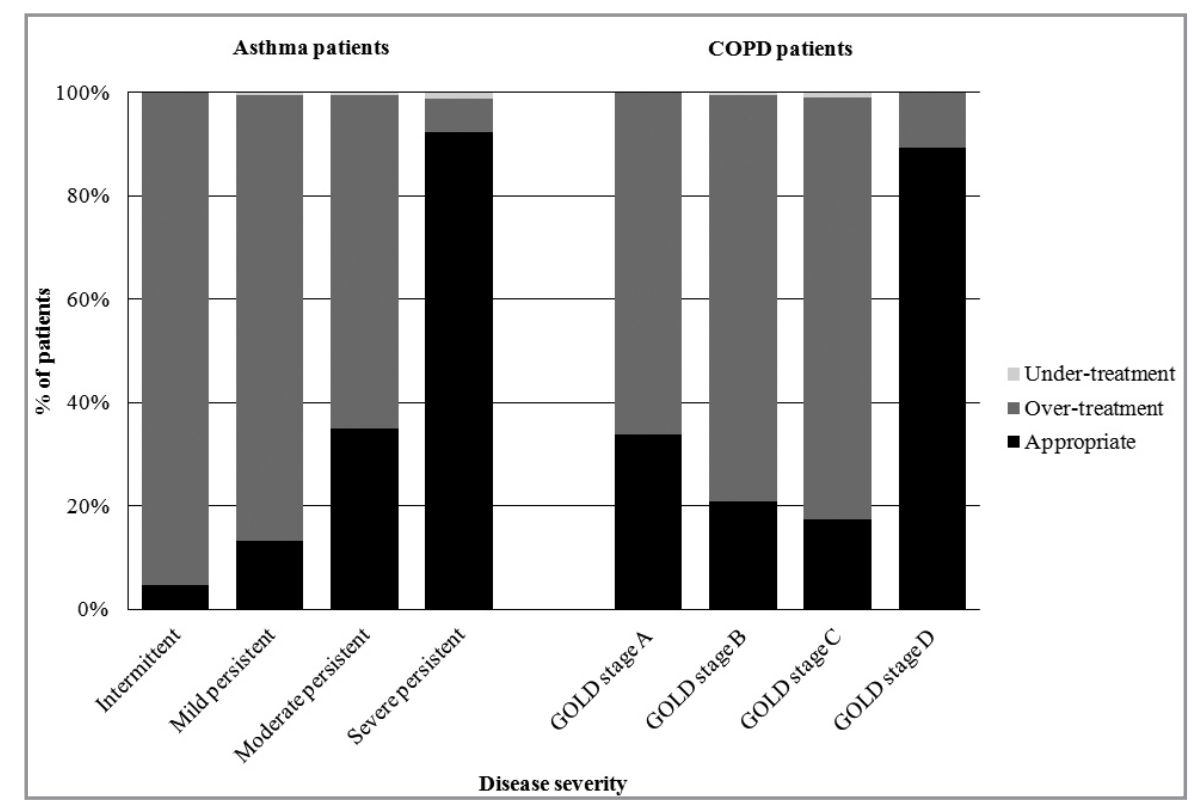

Figure 1. Adherence to recommendations of clinical guidelines regarding medication use in patients with asthma/chronic obstructive pulmonary disease (COPD) in different disease severity classes and stages. The disease severity groups show statistically significant differences in terms of adherence to guidelines in both patient groups $(p<0.001)$. 


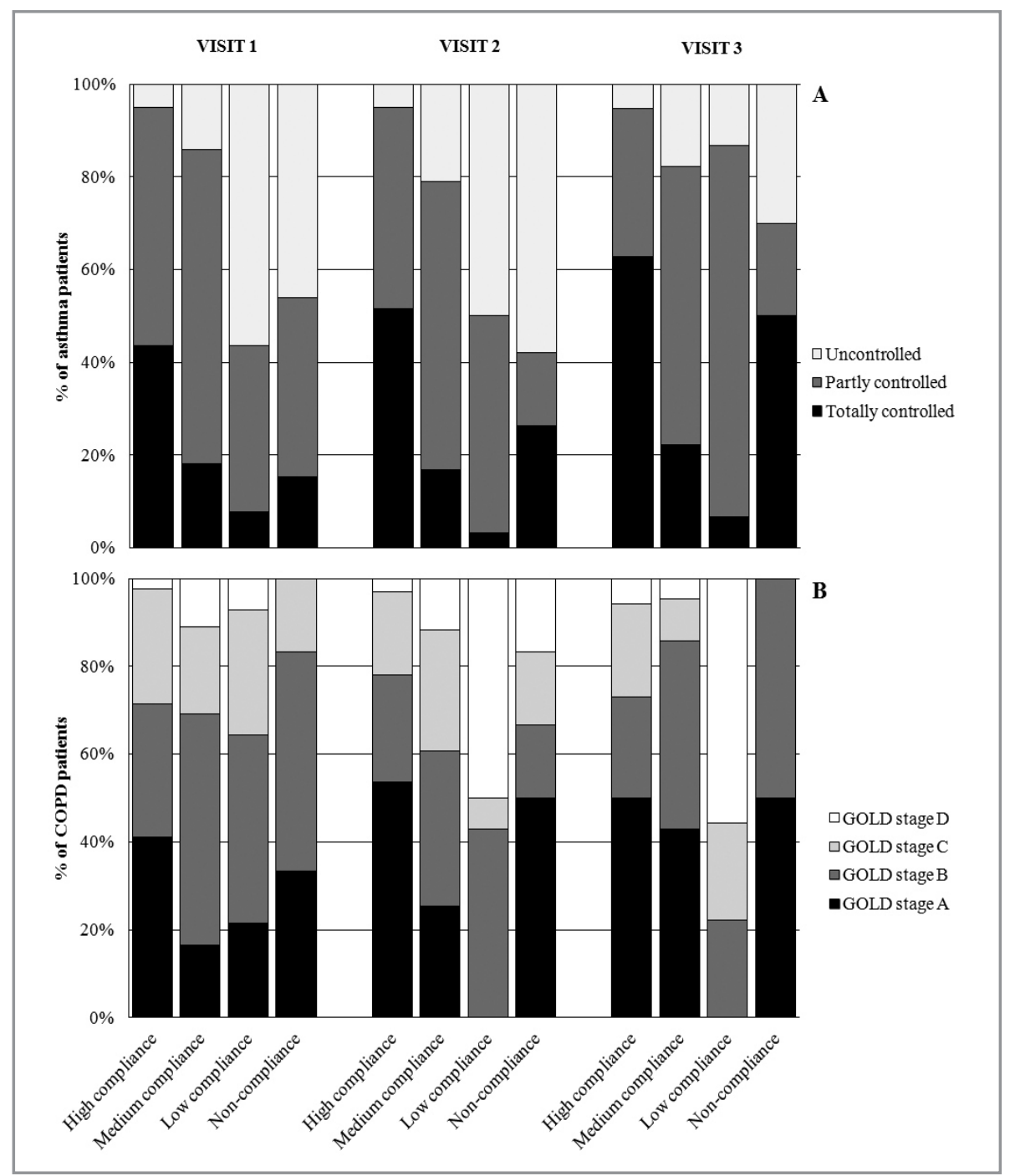

Figure 2. The disease control level of asthma patients and disease severity of chronic obstructive pulmonary disease (COPD) patients with different levels of treatment compliance during the follow-up. For asthma patients, the disease control levels show statistically significant differences among groups with different compliance to treatment levels in all three visits $(p<0.001)$. For COPD patients, the disease severity levels show statistically significant differences among groups with different compliance to treatment levels at all three visits $(p=0.038$, at visit- $1 ; p<0.001$, at visit- 2 , and $p=0.010$, at visit-3).

percentage of patients with GOLD stage B and C disease severity showed a gradual decrease.

\section{DISCUSSION}

The present multi-centre, non-interventional study demonstrates the data related to real life practice and outcomes of Turkish asthma/COPD patients by examining their clinical and demographical characteristics. The major purpose of the study was to wwcompare the disease characteristics among newly diagnosed treatment-naïve patient groups. In addition to this, the study also evaluated medication preferences of the physicians in real life practice. Our disease severity data revealed that $53.5 \%$ of the asthma patients had moderate persistent or severe persistent asthma and $35.1 \%$ of COPD patients had GOLD stage $\mathrm{C}$ or $\mathrm{D}$ disease severity. Thus, one of the important findings of our study was that both asthma and COPD patients had a considerable high disease severity at the time of diagnosis. This might be explained by the fact that they are underdiagnosed at the onset of the disease. It may also be the result of a delay in 
consulting a physician. The slowly progressive nature of COPD means that the disease usually remains undetected for many years, and most patients are first identified when they present with an exacerbation. Often, recognition of COPD does not occur until the disease has progressed to moderate or severe stages, by which time patients' symptoms have worsened (10). By the time COPD is diagnosed at a later stage of disease when the need for healthcare utilisation is high (11).

A previous study conducted in Turkey demonstrated that COPD patients are not diagnosed in early stage (12). It is also important to recognize that patients may display a lack of awareness of the disease. Failing to identify symptoms at the start of the disease, accepting breathlessness and reduced exercise tolerance as part of normal aging, or attributing cough and sputum to their smoking habit are the common attitudes in COPD patients. A study which was designed and performed as a Global Alliance Against Respiratory Disorders (GARD) project including 8342 people showed that awareness of asthma/COPD is insufficient among Turkish people (13). Thus, the implementation of appropriate education programs for both patients and physicians aiming to improve strategies for disease management and to increase the patients' compliance to visits might be considered.

Although management approaches and goals for asthma and COPD differ, both involve lifestyle modification concomitant with pharmacotherapy. As smoking is known to accelerate loss of lung function, smoking cessation is a high priority in COPD patients. Active smoking is also a critical factor in the risk of poor asthma control (14-16). Thus, lifestyle modification begins with smoking cessation, regardless of the diagnosis. In a previous study by Günen et al. the smoking rate and COPD prevalence were found to be unexpectedly high in Malatya region of Turkey (17). In our study, $56 \%$ of COPD and $28 \%$ of asthma patients are active smokers. In the clinical practice, active smokers with dyspnoea are frequently diagnosed with COPD. However, many recent papers have reported that cigarette smoking is surprisingly frequent in asthma patients, with a prevalence that is relatively close to that found in the general population (18-20). Our data revealing the high percentage of active smokers among asthma patients imply that asthma should also be considered for these patients in differential diagnosis. In addition to this, second-hand smoke is a particular problem for people with asthma, as it directly triggers asthma episodes and increases airway responsiveness to irritants and allergens (21). As the most common trigger factor is air pollution in our study $(65.4 \%$ and $60.7 \%$ for asthma and COPD, respectively), efforts to control environmental air pollution are also essential to help minimizing the exacerbation risk especially in asthma patients (22).

In this study, we also evaluated whether the physicians follow the medication recommendations described in the guidelines for their patients or not. Although it might be speculated that the clinical practice of the physicians may show variations, our study was conducted by 11 asthma/COPD specialists from various hospitals ( 9 university hospitals, 1 state hospital and 1 private hospital) from different geographic regions selected from a list of institutions to represent the whole country. Our analysis demonstrated that the majority of asthma patients with intermittent, mild persistent and moderate persistent disease severity and COPD patients with GOLD stage A, B and C disease severity is over-treated. The adherence level of the physicians to guidelines seems to be appropriate in $93 \%$ of the asthma patients with severe persistent disease severity and $89 \%$ of the COPD patients with GOLD stage D. Thus, these findings imply that the clinicians may not follow the medication algorithm described in the guidelines at all times. On the other hand, the current studies show that low adherence to GINA and GOLD guideline recommendations has been reported worldwide $(7,23,24)$. One possible explanation physicians' preference for a more aggressive treatment than usual would be that patients delay to visit a physician in the early phase of the disease; thus, they require a more aggressive treatment than usual at the time of their visit. The other possible explanation might be that the physicians consider the patients' risk factors while prescribing the medication. This is in line with our data showing a considerably high level of smoking and obesity in patients. Thus, in addition to implementing strategies to raise patient awareness, implementing education programs for physicians to update their level of knowledge would be effective interventions which would otherwise lead to a substantial increase in the economic burden of the disease in long-term basis.

Effective disease management of asthma/COPD includes a proper diagnosis, environmental control and control of adherence. Follow-up visits should include checking adherence/compliance to the medication plan and recommendations for reducing 
exposure to risk factors and should take place at regular intervals. Adherence rates in asthma and COPD are known to vary from $22 \%$ to $78 \%$ (25-27). Although treatment success in asthma and COPD is largely dependent upon medication adherence, suboptimal disease management, including the failure of physicians to adhere to treatment guidelines, also plays a part (28). Good adherence is associated with reduced exacerbation rates in patients with asthma and COPD (29-31). A subgroup analysis of the TORCH (Towards a Revolution in COPD Health) study showed that good compliance to study medication in patients with COPD was associated with lower mortality rates compared with poor compliance $(11.3 \%$ vs. $26.4 \%)$ (32). Findings of a study by Kocabaş et al. revealed that COPD patients continue to expose to risk factors and that their compliance to treatment is poor (33). Additionally, the socioeconomic status such as income, education, occupationcould also be associated with adherence to treatment among asthma/ COPD patients. As, the majority of our patients had low education level, the possible impact of the patients' socioeconomic status on their compliance to treatment and adherence to visits should be investigated further.

In our analysis, the disease control level of the asthma patients with high compliance to treatment markedly improved during the follow-up. Among those with high compliance, the percentage of patients with total control increased from $44 \%$ at visit- 2 to $63 \%$ at visit-3. Among those with high compliance, the percentage of patients with uncontrolled disease was only $5 \%$ in all three visits. Similarly, among COPD patients with high compliance, the percentage of those in GOLD stage $A$ disease severity increased from $41 \%$ to $54 \%$ between visit-1 and visit-2. On the other hand, the patient's individual perception of the disease severity makes the interpretation of these data complicated. That is, a patient who does not feel well may become either more compliant to treatment to feel better or less compliant thinking that the medication is ineffective. This issue is one of the limitations of our study. As the patients' adherence to visits during 1-year of follow-up is poor in our population, the parameters including medication adherence, medication efficiency and disease prognosis could not be evaluated in patients with poor adherence to visits. However, this limitation is an expected consequence of the real world studies.

This study presents the data of a non-interventional, real world observations and it is the first study that is conducted on newly diagnosed, treatment-naïve asthma/COPD patients in Turkey. The major limitation of the study is that the follow-up of patients was not regular due to the study design. Yet, we suggest that the education programs for general public, especially in a school or occupational setting, about asthma/COPD are required to enable members of the public to recognise disease symptoms and their consequences and encourage those with asthma/COPD to seek medical attention and follow their disease management program. In addition to implementing targeted campaigns to raise public awareness of the disease and early symptoms, it is also necessary to design educational interventions for patients to increase their understanding of the disease, and improve selfmanagement. Education programs can be delivered individually or in group sessions, either through faceto-face contact or remote communication via telephone or email.

In conclusion, improving the awareness and adherence to guidelines to help in early diagnosis, and also adherence to follow-up visits which include checking adherence/compliance to the medication plan may be the key of better health outcomes in patients with asthma/COPD.

\section{ACKNOWLEDGEMENTS}

ASKO Study Group consisted of following centres (listed according to the number of patients enrolled): Gulden Bilgin, Ankara Education and Research Hospital; Ahmet Cemal Pazarli, Elbistan State Hospital; Fatma Toksoy, Ahi Evren Thoracic and Cardiovascular Surgery Education and Research Hospital; Mahmut Recper, Pazarcik State Hospital; Selma Altun, Ahi Evren Thoracic and Cardiovascular Surgery Education and Research Hospital; Semih Aganoglu, Sar Hospital; Hayrullah Golen, Sivas State Hospital; Pelin Duru Cetinkaya, Cukurova Dr. Askim Tufekci State Hospital; Neslihan Ozcelik, Karadeniz Technical Univ. Faculty of Medicine; Ece Kaya, Salihli State Hospital; Pinar Mutlu, Artvin State Hospital; Aysegul Baysak, Izmir Medical Park Hospital; Kahraman Sahin, Yasam Hospital; Yavuz Havlucu, Celal Bayar Univ. Faculty of Medicine Pulmonary Diseases Hospital; Ayhan Gulsoy, Ahi Evren Thoracic and Cardiovascular Surgery Education and Research Hospital; Nilgun Yilmaz Demirci, Ataturk Thoracic Surgery and Pulmonary Diseases Education and Research Hospital; Ebru Celik, Unye State Hospital; Levent Cem Mutlu, Namik Kemal University; Munevver Mertsoylu Aydin, Kayseri Education and Research Hospital; Ahmet Akin, Sakarya Hospital; Ege Gulec Balbay, Duzce Univ. Faculty of Medicine; Gokhan Asal, Andeva Yildiz Hospital; Gulhan Bogatekin, Diyarbakir Education and Research Hospital; Sevilay Cicek, Esenyurt State Hospital; Serife Torun, Beyhekim State Hospital; Yavuz Alp Yalcin, Metropol Medical Centre; Yildiz Ucar, Seyrantepe Hospital; Adem Yilmaz, Cukurova Dr. Askim Tufekci State Hospital; Begum Kocar, Okmeydani Education and Research Hospital; Behiye Akkalyoncu, Ataturk Thoracic Surgery and Pulmonary Diseases Education and Research Hospital; Bilun Gemicioglu, Istanbul Univ. Cerrahpasa Faculty of Medicine; Dilek Saka, Ataturk Thoracic Surgery and Pulmonary Diseases Education and Research Hospital; Emrah Batmaz, Igdir State Hospital; Funda Senel, Mehmet Akif Ersoy Kucukcekmece Polyclinics; Hasan Ergen, Giresun Dr. Ali Menekse Pulmonary Diseases Hospital; Ibrahim Kilic, Ulus State Hospital; Mecit Suerdem, Selcuk Univ. Faculty of Medicine; Mustafa Dundar Temelli, Biga State Hospital; Mustafa Faysal Baysal, Adana Hospital; Nazire Ucar, Ataturk 
Real life profile of asthma and chronic

obstructive pulmonary disease patients in Turkey

Thoracic Surgery and Pulmonary Diseases Education and Research Hospital; Nurdan Kokturk, Gazi Univ. Faculty of Medicine; Ozlem Olgunus, Cukurova Dr. Askim Tufekci State Hospital; Serdar Polat, Bismil State Hospital; Utku Tapan, Karaman State Hospital; Umit Ozbek, Milas State Hospital; Zeynep Bozkurt, Alanya State Hospital; Aysel Talan, Nevsehir State Hospital; Ayse Cosar, Sivas Numune Hospital; Fatih Turan, Kocaeli State Hospital; Kezban Yorukoglu, Burhaniye State Hospital; Mehmet Altunisik, Malatya State Hospital; Omur Aydin, Ankara Univ. Faculty of Medicine; Seval Acar, Usak State Hospital; Canan Bol, Kayseri Nuh Naci Yazgan Pulmonary Diseases Hospital; Ozcan Avci, Bursa State Hospital; Sevtap Gulgosteren, Ataturk Thoracic Surgery and Pulmonary Diseases Education and Research Hospital; Aysegul Calli, Beyhekim State Hospital; Fatma Ciftci, Ankara Univ. Faculty of Medicine; Hur Isguder, Zile State Hospital; Yeliz Karakan, Gaziantep 25 Aralik State Hospital; Zeki Yildirim, Cekirge State Hospital; Mine Onal, Ataturk Thoracic Surgery and Pulmonary Diseases Education and Research Hospital; Orhan Akkaya, Tarsus State Hospital; Zafer Hasan Ali Sak, Harran Univ. Faculty of Medicine; Banu Altoparlak, Avrasya Hospital; Erkan Yildirim, Luleburgaz State Hsopital; Goksel Saygin, Ceyhan State Hospital; Gul Seyda Keskin, Haydarpasa Numune Education and Research Hospital; Kamil Ozdemir, Bilecik State Hospital; Mehmet Hakan Bilgin, Van Education and Research Hospital; Suleyman Kalan, Isparta State Hospital; Toros Ziya Selcuk, Hacettepe Univ. Faculty of Medicine; Ayse Dalli, Diyarbakir Education and Research Hospital; Murat Avsar, Megapark Hospital; Didem Katar, Etlik Specialist Education and Research Hospital; Ozgur Ince, Samsun Pulmonary Diseases Hospital; Ayla Kocatepe, Kartal Kizilay Medical Centre; Nesrin Yontem Gok, Aksehir State Hospital; Tuba Kiratli Karakaya, Evliya Celebi Hospital; Yalcin Dutkun, Aksaray Pulmonary Diseases Hospital; Esin Polat Yenturk, Yedikule Pulmonary Diseases Hospital; Hakan Koca, Buca Medical Centre; Ismail Hanta, Cukurova Univ. Faculty of Medicine; Nesrin Sariman, Maltepe Univ. Faculty of Medicine; Oznur Abadoglu, Sivas Cumhuriyet Univ. Faculty of Medicine; Ayse Bahadir, Yedikule Pulmonary Diseases Hospital; Tulay Yarkin, Sureyyapasa Pulmonary Diseases Hospital; Engin Kirmizigul, Tunceli State Hospital; Gulper Ozturk, Menemen State Hospital; Hayrettin Gocmen, Bursa Inegol State Hospital; Ilke Evciler, Menemen State Hospital; Aysenaz Taskin Ozcan, Ataturk Thoracic Surgery and Pulmonary Diseases Education and Research Hospital; Ender Levent, Maltepe Univ. Faculty of Medicine; Esat Hayat, Gumushane State Hospital; Murat Sezer, Bezmialem Univ. Faculty of Medicine; Sabri Serhan Olcay, Gediz State Hospital; Sule Tas Gulen, Mardin State Hospital; Yurdanur Sahin, Alanya State Hospital; Fusun Fakili, Adiyaman State Hospital; Metin Tek, Antalya Education and Research Hospital; Nigar Halis, Esenler Hayat Hospital and Silivri Hayat Hospital; Ayse Gul Oney Kurnaz, Sanliurfa Education and Research Hospital; Esma Ozturk, Denizli State Hospital; Firdes Kervan, Yildirim Beyazit Education and Research Hospital; Huseyin Beyazit, Damla Hospital; Zeynep Atam Tasdemir, Bagcilar Education and Research Hospital; Evsen Coskun, Lokman Hekim Esnaf Hospital; Ahmet Oguz Aktas, Sureyyapasa Pulmonary Diseases Hospital; Aysenur Eroglu, Sultanbeyli State Hospital; Bahri Temuray, Ibni Sina Hospital; Cenk Babayigit, Mustafa Kemal Univ Faculty of Medicine; Suna Akbulut, Afyon Pulmonary Diseases Hospital; Aylin Celikhisar, Esrefpasa Pulmonary Diseases Hospital; Aysun Sengul, Kocaeli Derince Education and Research Hospital; Goksel Bahadir, Beylerbeyi Kupluce Medical Centre; Hakan Celikhisar, Cigli State Hospital; Kemal Can Tertemiz, Ege Saglik Izmir Hospital; Zehra Dilek Kanmaz, Yedikule Pulmonary Diseases Hospital; Hakan Altinbas, Manavgat State Hospital; Hulya Koksal, Kirikkale State Hospital; Sule Kaya, Bayburt State Hospital.

Oktay Ozdemir (Assoc. Prof., MD) performed the statistical analysis of the study data. Murat Kirtis and Elif Ograli wrote and edited the manuscript. All authors read, edited and approved the final manuscript.

\section{FUNDING}

The study is financially supported by "Abdi Ibrahim Ilac San. ve Tic. AS, Turkey". All authors are members of the advisory board of the study and received payment from "Abdi Ibrahim Ilac San. ve Tic. AS, Turkey" for this.

\section{REFERENCES}

1. Chang J, Mosenifar Z. Differentiating COPD from asthma in clinical practice. J Intensive Care Med 2007:22;300-9.

2. Kjeldgaard P, Dahl R, Lokke A, Ulrik CS. Detection of COPD in a high-risk population: Should the diagnostic work-up include bronchodilator reversibility testing? Int I Chron Obstruct Pulmon Dis 2015:10;407-14.

3. Wouters EF. Local and systemic inflammation in chronic obstructive pulmonarydisease. Proc Am Thorac Soc 2005;2:26-33.

4. Bjermer L. Time for a paradigm shift in asthma treatment from relieving bronchospasm to controlling systemic inflammation. J Allergy Clin Immunol 2007;120:1269-75.

5. Braido F, Biardini I, Blasi F, Pawankar R, Canonica GW. Adherence to asthma treatments: 'we know, we intend, we advocate.' Curr Opin Allergy Clin Immunol 2015, 15:49-55.

6. Gillissen $A$, Wirtz $H$, Juergens $U$. Patient and physician factors contributing to poor outcomes in patients with asthma and COPD. Dis Manage Health Outcomes 2007; 15:355-76.

7. Şen E, Güçlü SZ, Kibar I, Öcal L, Yılmaz V, Çelik O, et al. Adherence to GOLD guideline treatment recommendations among pulmonologists in Turkey. Int J Chron Obstruct Pulmon Dis 2015:10;2657-63.

8. Global Initiative for Asthma (GINA). Global strategy for asthma management and prevention 2012 update: NHLBI/WHO Workshop Report. Bethesda: National Institutes of Health, National Heart, Lung and Blood Institute. Accessed date: 5 February 2016. Available from: http://www.ginasthma.org. (updated April 2015).

9. Global Initiative for Chronic Obstructive Lung Disease (GOLD).Global Strategy for the Diagnosis, Management and Prevention of COPD. Revised 2011. Accessed date: 5 February 2016. Available from: http://www.goldcopd. org. (updated December 2015).

10. Walters JA, Hansen EC, Walters EH, Wood-Baker R. Underdiagnosis of chronic obstructive pulmonary disease: a qualitative study in primary care. Respir Med 2008;102:738-43.

11. Blanchette $C M$, Roberts MH, Petersen H, Dalal AA, Mapel $D W$. Economic burden of chronic bronchitis in the United States: a retrospective case-control study. Int I Chron Obstruct Pulmon Dis 2011;6:73-81.

12. Turkey Burden of Disease Study 2004. The Ministry of Health of Turkey, Refik Saydam Hygiene Center, School of Public Health 2004, Ankara, Turkey. Accessed date: 5 February 2016. Available from: http://ekutuphane.sagem. gov.tr/kitaplar/turkey_burden_of_disease_study.pdf.

13. Yıldız F, Bingöl Karakoç G, Ersu Hamutçu R, Yardım N, Ekinci B, Yorgancıoğlu A. The evaluation of asthma and COPD awarenessin Turkey (GARD Turkey ProjectNational Control Program of Chronic Airway Diseases). Tuberk Toraks 2013;61:175-82. 
14. Demoly P, Gueron B, Annunziata K, Adamek L, Walters $R D$. Update on asthma control in five European countries: results of a 2008 survey. Eur Respir Rev 2010;19:150-7.

15. McLeish AC, Zvolensky MJ. Asthma and cigarette smoking: a review of the empirical literature. J Asthma 2010;47:345-61.

16. Aanerud M, Carsin AE, Sunyer J, Dralva J, Gislason T, Janvis $D$, et al. Interaction between asthma and smoking increases the risk of adult airway obstruction. Eur Respir J 2015:45;635-43.

17. Günen H, Hacievliyagil SS, Yetkin $O$, Gülbaş G, Mutlu LC, Pehlivan E. Prevalence of COPD: first epidemiological study of a large region in Turkey. Eur I Intern Med 2008;19:499-504.

18. Thomson NC, Chaudhuri R, Livingston E. Asthma and cigarette smoking. Eur Respir I 2004;24:822-33.

19. Boulet LP, Lemière C, Archambault F, Carrier G, Descary MC, Deschesnes F. Smoking and asthma: clinical and radiologic features, lung function, and airway inflammation. Chest 2006;129:661-8.

20. Boulet LP, Dorval E, Labrecque $M$, Turgeon M, Montague $T$, Thivierge RL. Towards Excellence in Asthma Management: final report of an eight-year program aimed at reducing care gaps in asthma management in Quebec. Can Respir J 2008; 15:302-10.

21. Silvestri $M$, Franchi S, Pistorio A, Petechia L, Rusconi F. Smoke exposure, wheezing and asthma development. A systematic review and metaanalysis in unselected birth cohorts. Ped Pulmon 2015:50;353-62.

22. Yıldırım N, Demir T, Gemicioğlu B, Kıyan E, Oguzülgen K, Polatı $M$, et al. COPD and asthma exacerbations. Tuberk Toraks 2015:63;111-31.

23. Sharif $R$, Cuevas $C R$, Wang $Y$, Arora $M$, Sharma G. Guideline adherence in management of stable chronic obstructive pulmonary disease. Respir Med 2013:107; 1046-52.

24. Chou CL, Perng DW, Lin TL, Lin AMY, Chin TJ, Wu MS, et al. Analysis of prescription pattern and guideline adherence in the management of asthma among medical institutions and physician specialities in Taiwan between 2000 and 2010. Clin Ther 2015:37;2275-85.

25. Bender BG, Pedan A, Varasteh LT. Adherence and persistence with fluticasone propionate/salmeterol combination therapy. I Allergy Clin Immunol 2006; 118:899-904.
26. Makela MI, Backer V, Hedegaard M, Larsson K. Adherence to inhaled therapies, health outcomes and costs in patients with asthma and COPD. Respir Med 2013;107:1481-90.

27. Krigsman K, Nilsson JL, Ring L. Refill adherence for patients with asthma and COPD: comparison of a pharmacy record database with manually collected repeat prescriptions. Pharmacoepidemiol Drug Saf 2007; 16:4418.

28. Restrepo RD, Alvarez MT, Wittnebel $L D$, Sorenson $H$, Wettstein $R$, Vines $D L$, et al. Medication adherence issues in patients treated for COPD. Int J Chron Obstruct Pulmon Dis 2008;3:371-84.

29. Williams $L K$, Peterson EL, Wells $K$, Ahmedani BK, Kumar $R$, Burchard EG, et al. Quantifying the proportion of severe asthma exacerbations attributable to inhaled corticosteroid nonadherence. J Allergy Clin Immunol 2011;128:118591e2.

30. Marceau C, Lemiere C, Berbiche D, Perreault S, Blais L. Persistence, adherence, and effectiveness of combinationtherapy among adult patients with asthma. I Allergy Clin Immunol 2006;118:574-81.

31. Toy EL, Beaulieu NU, MCHale JM, Welland TR, Plauschinat $C A$, Swensen A, et al. Treatment of COPD: relationships between daily dosing frequency, adherence, resource use, and costs. Respir Med 2011;105:435-41.

32. Vestbo J, Anderson JA, Calverley PM, Celli B, Ferguson GT, Jenkins $C$, et al. Adherence to inhaled therapy, mortality and hospital admission in COPD. Thorax 2009;64:93943.

33. Kocabaş A, Hancıoğlu A, Türkyılmaz $S$, Ünalan T, Umut $S$, Çakır B, et al. Prevalence of COPD in Adana, Turkey (BOLD-Turkey Study). Proc Am Thorac Soc 2006; 3:A543. 